\title{
JURNAL
}

\section{Implementasi dan modifikasi WebShell untuk monitoring serangan berbasis website}

\author{
Paulus Miki Resa Gumilang ${ }^{1)}$, Dian Widiyanto Chandra ${ }^{2)}$ \\ 1) 2)Fakultas Teknologi Informasi, Universitas Kristen Satya Wacana \\ J1. Dr. O. Notohamidjojo 1-10, Salatiga 50711, Indonesia \\ Email : ${ }^{1)} 672017055 @$ student.uksw.edu ,2)dian.chandra@uksw.edu
}

\begin{tabular}{|c|c|c|}
\hline Recieved: 27-05-2021 & $\begin{array}{c}\text { Riwayat artikel: } \\
\text { Revised: } 16-07-2021\end{array}$ & Accepted: $18-07-2021$ \\
\hline
\end{tabular}

\section{Abstract}

Backdoor is a code commonly used by hackers to gain access to a web page illegally, backdoor or also called a webshell at this time is still very often used by hackers to carry out attacks on a web page, but in handling attacks using a webshell it is not always possible to detected quickly and even take months to realize the web page has embedded webshell. To deal with these problems, we need an application that can quickly detect attacks carried out by embedding a webshell on a web page. The purpose of this study is to modify an existing webshell so that it can be monitored when used by hackers to attack a website, the monitoring process is carried out using a web page created by the author. The results of the discussion of this study can be used to quickly detect attacks that using modified webshell.

Keywords: backdoor, webshell, visualization, monitoring, logs

\begin{abstract}
Abstrak
Backdoor merupakan kode yang biasa digunakan oleh peretas untuk mendapatkan akses pada suatu halaman web secara ilegal, backdoor atau disebut juga webshell pada saat ini masih sangat sering digunakan oleh peretas untuk melakukan serangan pada suatu halaman web, namum pada penanganannya serangan yang menggunakan webshell tidak selalu dapat dideteksi dengan cepat bahkan memerlukan waktu berbulan-bulan untuk menyadari halaman web telah tertanam suatu webshell. Untuk menangani permasalahan tersebut maka dibutuhkan suatu aplikasi yang dapat mendeteksi secara cepat serangan yang dilakukan dengan cara menanamkan webshell pada suatu halaman web. Tujuan dari penelitian ini adalah memodifikasi webshell yang sudah ada supaya dapat dimonitoring ketika digunakan oleh peretas untuk menyerang suatu website, proses monitoring dilakukan dengan menggunakan halaman web yang dibuat penulis. Hasil pembahasan dari penelitian ini dapat digunakan untuk mendeteksi dengan cepat serangan yang menggunakan webshell yang telah dimodifikasi.
\end{abstract}

Kata kunci: backdoor, webshell, visualisasi, monitoring, log 


\section{Pendahuluan}

Setiap hari ada belasan sampai puluhan website penting milik pemerintah Indonesia (berdomain *.go.id) yang diretas, hal tersebut bisa dilihat berdasarkan informasi yang dikumpulkan oleh situs arsip defaced website (www.zone-h.org) [1], [2]. Maraknya aksi hacking yang dilakukan oleh Hacker dalam negeri maupun luar negeri yang dengan sengaja merubah tampilan, mengambil data dari suatu website milik orang lain atau instansi penting seperti situs organisasi, militer, pemerintahan milik Indonesia dirasa sangat miris dan patut dipertanyakan karena situs-situs penting terutama situs pemerintahan Indonesia yang menjadi muka Indonesia tentang seberapa besar kesadaran terhadap IT Security justru terkena aksi usil dari Hacker yaitu "Deface" [2]-[4]. Hal ini menunjukan bahwa kesadaran Indonesia terhadap dunia IT Security masih rendah untuk itu sangat perlu untuk lebih meningkatkan kesadaran dalam keamanan siber (cyber security awareness) [5]. Masalah ini merupakan tamparan keras bagi kita semua agar kedepannya Negara ini menjadi bangsa yang besar dan mampu bersaing dalam Cyber Security di kancah Internasional [3], [6].

Deface merupakan suatu kegian merubah tampilan suatu website. Biasanya Hacker melakukan deface dengan cara menanamkan backdoor terlebih dahulu dengan berbagai macam cara. Kemudian Hacker menggunakan backdoor tersebut untuk melakukan gaining access [7], [8]. Namum karena sulitnya mengidentifikasi file backdoor sehingga pada penanganannya serangan ini tidak selalu dapat dideteksi dengan cepat bahkan memerlukan waktu berbulan-bulan untuk menyadari halaman web telah tertanam suatu backdoor [9].

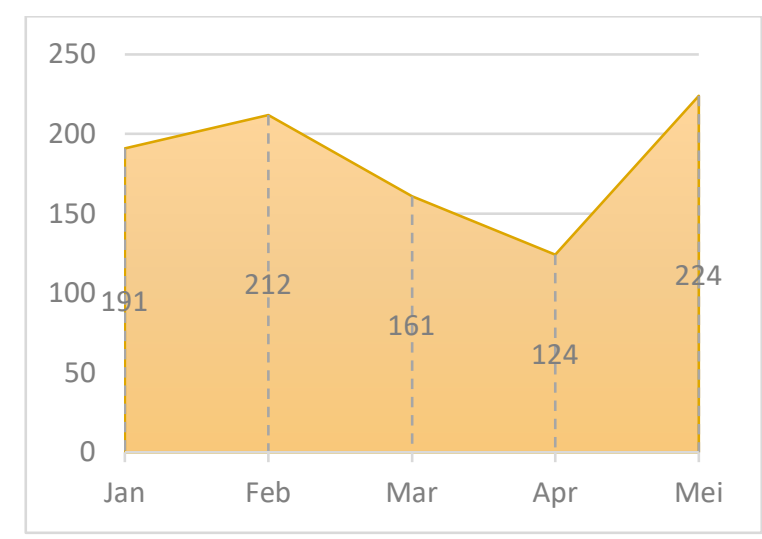

Gambar 1 Grafik Serangan Deface pada website (berdomain *.go.id) tahun 2021

Gambar 1 menunjukkan grafik serangan deface pada website (berdomain * go.id) pada tahun 2021. Data yang digunakan pada grafik tersebut didapatkan dari hasil scraping pada website (www.zone-h.org), tidak semua serangan deface terdaftar pada situs zone-h.org oleh karena itu jumlah serangan deface bisa saja lebih besar dari data yang penulis dapatakan, namum dengan angka sebesar itu bisa dibilang jumlahnnya sudah sangat banyak mengingat domain *.go.id merupakan 
domain yang digunakan oleh pemerintah Indonesia yang seharusnya mendapatkan perhatian lebih dibanding domain-domain lain tapi justru malah menjadi domain yang paling banyak terkena serangan deface dibandingkan dengan Country Code Top Level Domain (ccTLD) .id lainnya [1].

Sudah banyak beredar di internet backdoor yang bisa didapatkan secara gratis dengan berbagai macam fitur yang ada. Namum backdoor yang beredar kebanyakan digunakan hanya untuk melakukan serangan dan belum ada yang memanfaatkan webshell backdoor untuk digunakan sebagai jebakan untuk Hacker.

Webshell dimodifikasi agar ketika ditanam di suatu situs akan secara otomatis mengirim data berupa log ke email [10]. Webshell yang telah dimodifikasi tersebut kemudian disebar luaskan di internet agar didownload dan digunakan oleh penyerang. Ketika digunakan backdoor tersebut akan mengirim log ke email [10], [11], kemudian log tersebut akan diparsing ke database sehingga serangan bisa dimonitoring melalui website. Penelitian ini diharapkan akan membantu banyak pihak terutama instansi negara yang memiliki tugas menjaga keamanan cyber dalam memonitoring domain penting milik negara selain itu juga diharapkan dapat membantu Perusahaan Web Hosting dalam memonitoring serangan pada domain yang mereka jual.

\section{Kajian Pustaka}

Penelitian terkait sebelumnya dilakukan oleh Ramadhan [12] yang bertujuan untuk membahas strategi yang paling tepat dalam menjaga keamanan cyber di Kawasan Asia Tenggara. Penelitian ini juga membuktikan bahwa Cybersecurity perlu mendapatkan prioritas dalam studi keamanan karena pada saat ini banyak kebutuhan yang tidak dapat terlepas dari dunia maya bahkan kebutuhan negara-bangsa tidak dapat terlepas dari peranan dunia maya.

Fazlurrahman dan Hariyadi [1] membuat aplikasi yang dapat mengambil informasi open source (OSINT) dari website zone-h.org yang menyediakan informasi tentang web defacement yang telah dilaporan oleh peretas, kemudian informasi yang didapatkan akan divisualisasikan menggunakan ELK Stack. Pada penelitian ini disebutkan bahwa situs web dengan domain .go.id mendapat serangan web defacement terbanyak dibandingkan dengan Country Code Top Level Domain(ccTLD) .id lainnya. Serangan web defacement juga merupakan serangan yang memerlukan biaya untuk memperbaikinya. Pada proses penggunaannya aplikasi ini perlu dilakukan secara manual pada saat melakukan scraping menggunakan tool makaboro dan pada saat penyesuaikan isi dari file CSV hasil dari scraping sebelum diunggah ke mesin ELK Stack.

Mahmudi [9] membuat sistem pendeteksi backdoor yang sekaligus dapat dimanfaatkan untuk menemukan celah keamanan maupun Exploit yang digunakan 
peretas untuk menanam backdoor tersebut. Pada penelitian ini juga disebutkan bahwa penyebab suatu website dapat dengan mudah terserang oleh peretas hingga masuk kedalam web server salah satunya adalah karena masih kurangnya pengetahuan tentang cyber security. Penelitian ini menggunakan teknik IDS untuk mendeteksi aktifitas serangan pada web server, menggunakan data signature berupa base64_decode, eval, mysql_query, dan method GET/POST.

Hasibuan \& Gultom [13], meneliti tentang cara-cara yang bisa digunakan oleh hacker untuk mengupload webshell ke dalam suatu website dan kemudian melakukan deface pada website tersebut. Disini juga dijelaskan beberapa faktor yang mengakibatkan adanya vulnerability disebuah website. Penelitian ini juga membuktikan bahwa backdoor masih sering digunakan oleh para Hacker. Pada bagian akhir terdapat saran dari penelitian ini yaitu membuat suatu aplikasi khusus untuk dapat memberikan penanganan dini terhadap serangan.

Andriani, Pramukantoro dan Data [14] mengembangakan sebuah sistem yang dapat memvisualisasikan access log dari server apache. Access log diupload melalui website kemudian access log akan diparsing kemudian disimpan ke dalam database MySQL. Kemudian secara otomatis data akan divisualisasikan oleh sistem ke dalam bentuk grafik. Visualisasi log dibuat dengan tujuan untuk mempermudah membaca dan menganalisis log yang masih berbentuk data mentah.

Sopaheluwakan dan Chandra [3] menciptakan PHP Backdoor Scanner yang Update. Penelitian ini juga membuktikan bahwa WebShell atau Backdoor selalu berkembang, dan karena perkembangan itu membuat webshell sulit untuk dideteksi sehingga memerlukan tools scanning yang update.

Waliulu dan Jumame [15] mengembangkan sebuah framework ShellTrap yang memiliki fungsi untuk mendeteksi dan membersihkan backdoor atau webshell pada server, selain itu pada penelitian ini juga dijelaskan banyak metode atau cara yang biasa digunakan oleh peretas untuk melakukan serangan dan menanamkan backdoor pada website.

Berdasarkan penelitian-penelitian sebelumnya yang relevan dengan backdoor dan visualisasi log, dapat disimpulakan bahwa cyber security saat ini perlu mendapatkan prioritas dalam studi keamanan karena pada zaman ini sangat banyak kebutuhan yang sudah tidak dapat terlepas dari peranan dunia maya [12]. Serangan web defacement merupakan serangan yang memerlukan biaya untuk memperbaikinya [1]. backdoor selalu berkembang dan sering digunakan oleh hacker untuk gaining access pada suatu website [3]. Banyak cara yang bisa digunakan oleh hacker untuk menanan suatu backdoor pada website, backdoor selalu berkembang sehingga bisa disimpulkan tidak akan ada website yang aman apabila website tersebut keamanan nya tidak terupdate, tidak ada tool scanning ataupun anti backdoor yang ampuh apabila tidak terupdate [3], [9], [15]. Maka dari 
itu penelitian ini hadir untuk menjawab semua hal tersebut. Perbedaan-nya adalah penelitian ini tidak akan membuat tool yang digunakan untuk scanning backdoor atau software keamanan yang bisa melindungi website dari backdoor, namun penelitian ini akan memodifikasi backdoor yang ada agar menjadi jebakan bagi penggunanya, sehingga ketika backdoor yang telah dimodifikasi digunakan oleh hacker maka secara cepat serangan dapat diketahui melalui website yang memvisualisasikan log dari backdoor yang ditanam tersebut, sehingga bisa diketahui dengan cepat dimana backdoor tersebut ditanam, kapan, dan IP dari pengguna backdoor tersebut ketika backdoor tersebut digunakan oleh penyerang.

\section{Metode Penelitian}

Dalam pelaksanaan penelitian, penulis memilih Penelitian dan Pengembangan sebagai metode penelitian, dikarenakan penulis akan membuat sebuah program untuk membantu memecahkan masalah tentang pendeteksian serangan deface yang dilakukan menggunakan webshell pada website. Langkahlangkah dalam perancangan adalah sebagai berikut:

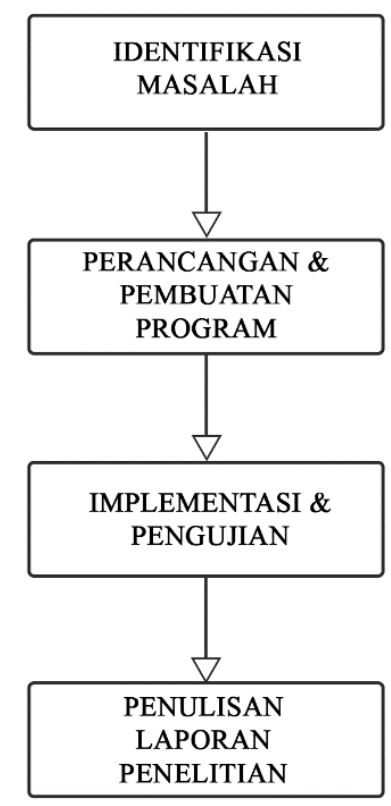

Gambar 2 Alur perancangan penelitian

Penjelasan dari gambar 1 adalah sebagai berikut:

a) Tahap Identifikasi Masalah: merupakan tahap awal dari penelitian dengan melakukan identifikasi terhadap masalah yang menjadi topik penelitian di lapangan secara aktual.

b) Tahap Perancangan dan Pembuatan Program: pada tahap kedua ini peneliti akan merancang dan membuat program menggunakan bahasa pemrograman PHP. 
c) Tahap Implementasi dan Pengujian: pada tahap ketiga, peneliti akan mengimplementasikan dan melakukan pengujian program yang telah dibuat ke domain dan website pribadi peneliti supaya tidak melanggar etika-etika yang ada.

d) Tahap Penulisan Laporan Penelitian: merupakan tahap akhir dimana peneliti akan mendokumentasikan hasil penelitian dengan menuliskan laporan penelitian

Alat-alat yang digunakan dalam melakukan penelitian ini adalah sebagai berikut :

a. Visual Studio Code

Adalah software text editor yang nantinya akan digunakan untuk melakukan modifikasi file WebShell, dan juga digunakan untuk pembuatan website yang digunakan untuk memvisualisasikan log.

b. Gmail

Gmail adalah layanan surat elektronik yang bisa digunakan untuk mengirim dan menerima email. Pada penelitian ini gmail digunakan untuk menerima log dari WebShell yang kemudian log yang masuk akan diforward untuk dilakukan parsing.

c. Parseur

Parseur merupakan tool yang digunakan untuk melakukan parsing pada isi email supaya isi email terbagi menjadi bagian-bagian yang sesuai dengan rules yang telah dibuat.

d. Zapier

Zapier merupakan tool yang digunakan untuk melakukan Export dari email yang sudah diparsing ke database.

e. MySQL

MySQL adalah salah satu jenis database yang nantinya akan digunakan untuk menampung data dari hasil parsing.

f. PhpMyAdmin

Adalah web yang digunakan untuk mengolah database MySQL.

g. Cpanel

Adalah panel control yang bisa digunakan untuk melakukan pengaturan hosting seperti managemen database, file, domain, security, email dan masih banyak lagi.

h. PHP Obfuscator

Tool yg digunakan untuk menyamarkan script PHP agar susah dipahami ketika dibaca. Script PHP akan menjadi sangat berantakan dan tulisannya akan dienkripsi. Tool ini sangat berguna untuk penelitian ini yaitu untuk menyamarkan script pada WebShell agar penguna tidak tau kalau WebShell telah dimodifikasi. Dan juga bermanfaat untuk membypass pendeteksian oleh Web Application Firewall ketika WebShell diupload karena WebShell biasanya terdeteksi sebagai malicious file. 
i. Laptop

Dalam proses modifikasi WebShell dan pembuatan Website dibutuhkan perangkat komputer yang nantinya digunakan untuk melakukan pengkodean.

\section{Hasil dan Pembahasan}

Proses penanaman WebShell yang telah dimodifikasi sampai divisualisasikan di website memiliki alur seperti yang ada di Gambar 3.

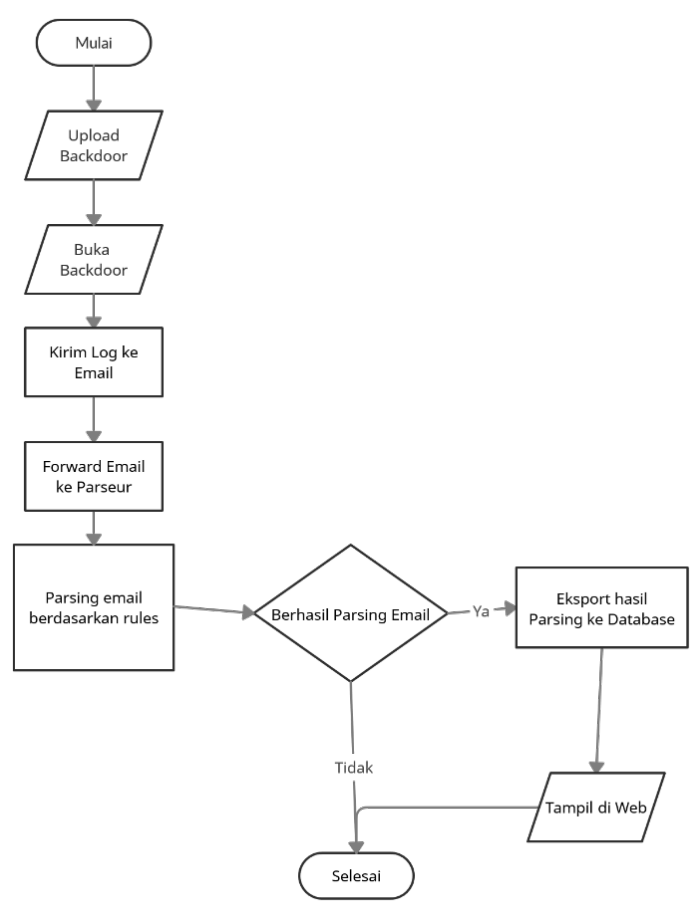

Gambar 3 Diagram alur kerja

Solusi yang didapatkan oleh penulis dalam memodifikasi webshell agar dapat mengirimkan email pada saat webshell tersebut ditanam pada suatu website oleh peretas adalah dengan menggunakan fungsi PHP Mail.

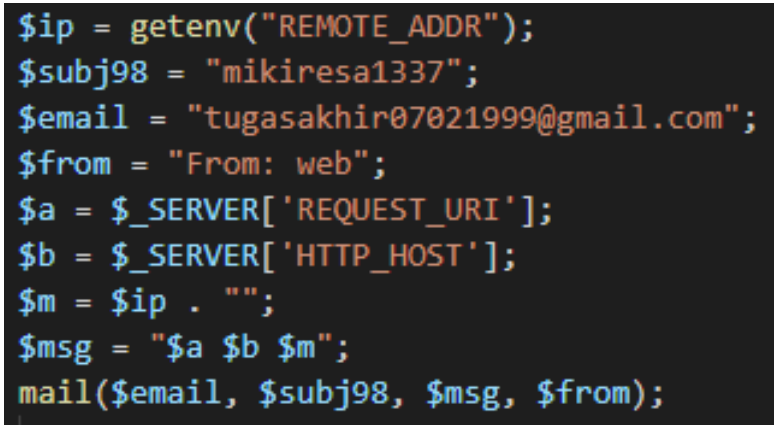

Gambar 4 Fungsi PHP Mail 
Gambar 4 merupakan fungsi PHP mail. Dengan menambahkan Fungsi PHP Mail pada WebShell, WebShell akan secara otomatis mengirimkan email pada saat ditanam pada suatu website dan kemudian dibuka oleh peretas. Penulis menambahkan beberapa Fungsi dan Variabel Sistem PHP didalamnya seperti getenv(“REMOTE_ADDR”),\$_SERVER['REQUEST_URI'], \$ SERVER ['HTTP_HOST'] yang nantinya hasil dari fungsi-fungsi tersebut akan dikirimkan oleh PHP Mail sebagai bagian isi pesan dari email tersebut.

Tabel 1 Fungsi dan Variabel Sistem PHP

\begin{tabular}{ll}
\hline \multicolumn{1}{c}{ Nama } & \multicolumn{1}{c}{ Kegunaan } \\
\hline getenv('REMOTE_ADDR") & $\begin{array}{l}\text { Mengirimkan alamat IP client atau } \\
\text { pengguna dalam hal ini adalah IP } \\
\text { dari penyerang. }\end{array}$ \\
\hline \$_SERVER['REQUEST_URI'] & $\begin{array}{l}\text { Mendapatkan direktori pada URL } \\
\text { sehingga lokasi dimana WebShell } \\
\text { ditanam akan terlihat. }\end{array}$ \\
\hline \$_SERVER['HTTP_HOST'] & $\begin{array}{l}\text { Mengirimkan alamat Domain } \\
\text { dimana WebShell ditanam. }\end{array}$ \\
\hline
\end{tabular}

Pada Tabel 1 merupakan Fungsi dan Variabel Sistem PHP berserta penjelasan tentang kegunaannya. Dengan mengunakan Fungsi dan Variabel Sistem PHP tersebut maka dapat menjadi solusi untuk memodifikasi WebShell agar dapat mengirimkan log berupa email pada saat WebShell ditanan dan dibuka.

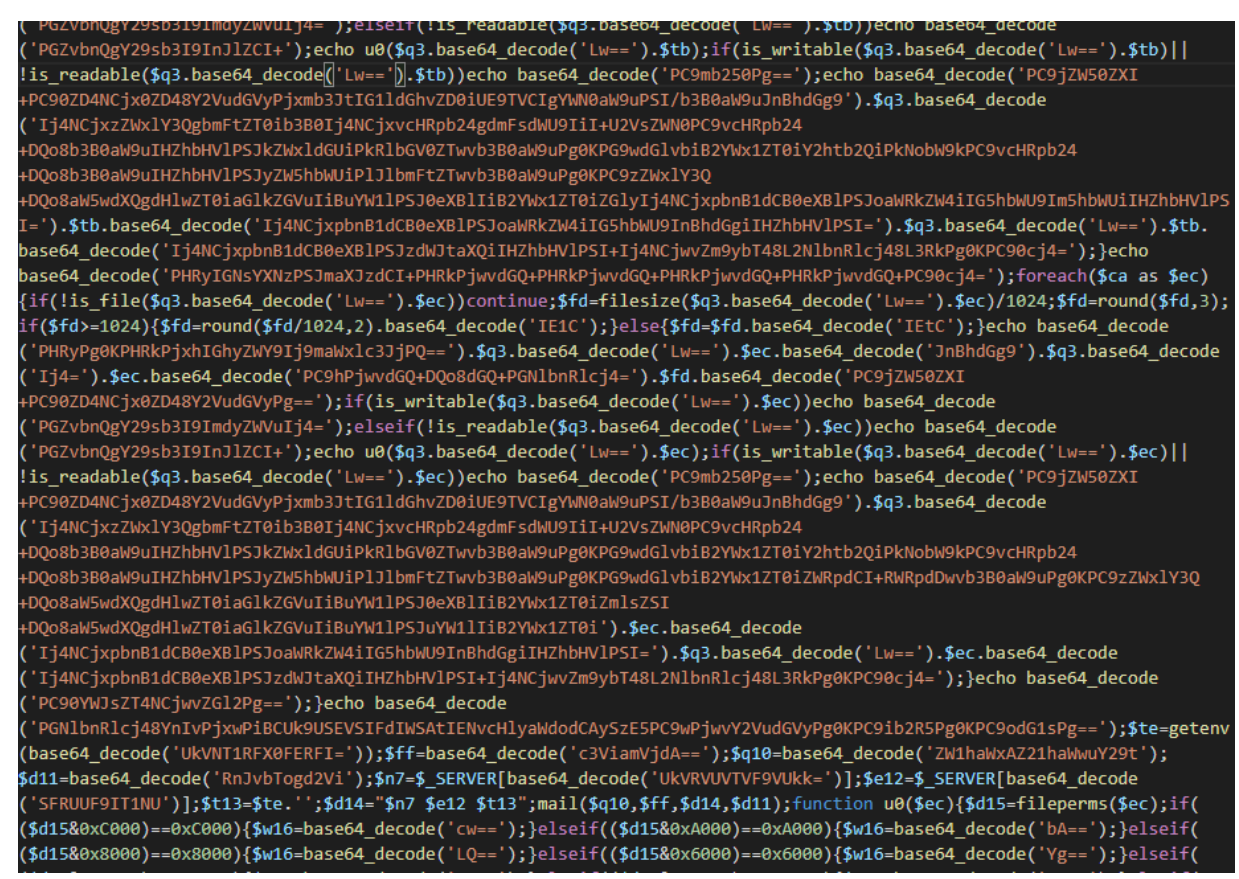

Gambar 5 Source code hasil PHP Obfuscator

Gambar 5 merupakan tampilan source code setelah diubah menggunakan tool PHP Obfuscator. WebShell yang telah dimodifikasi akan dapat diketahui oleh Peretas apabila source code yang ada didalam WebShell tidak disamarkan terlebih dahulu selain itu source code WebShell akan terdeteksi oleh Web Aplication 
Firewall (WAF) yang akan menyebabkan source code akan hilang ketika diupload. Untuk itu source code akan terlebih dahulu dirubah menggunakan tool bernama PHP Obfuscator, hasil dari PHP Obfuscator adalah source code akan terencode, spasi akan terhapus sehingga tulisan menjadi berantakan, nama variabel disamarkan, seluruh komen akan dihapus. Dengan menggunakan tool ini Peretas tidak akan dengan mudah mengetahui bahwa WebShell yang digunakan telah dimodifikasi, dan juga WebShell tidak akan terdeteksi oleh Web Aplication Firewall ketika diupload.

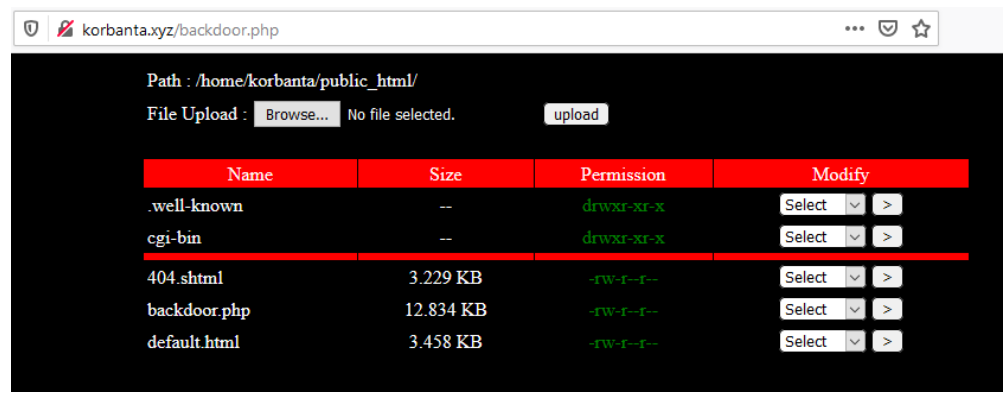

Gambar 6 Tampilan Backdoor

Gambar 6 merupakan tampilan WebShell yang telah ditanam dan dibuka. Untuk melakukan simulasi dan pengujian WebShell yang telah dimodifikasi, pada penelitian ini penulis hanya akan menanamkan WebShell pada website milik penulis agar tidak merugikan orang lain dan melanggar etika-etika yang ada. Oleh karena itu penulis telah menyiapkah hosting dan domain bernama korbanta.xyz yang kemudian akan ditanamkan WebShell dan kemudian dibuka sehingga WebShell akan mengirim email secara otomatis.

\section{mikiresa1337 Inbox $x$ \\ web@domain.com \\ to me - \\ /backdoor.php korbanta.xyz 36.72.216.26}

Gambar 7 email berisi log dari backdoor

Gambar 7 merupakan tampilan email berisi log dari WebShell yang ditanam. Agar email dapat dieksport ke database maka diperlukan proses parsing terlebih dahulu agar log yang ada pada bagian isi dari email bisa dibagi menjadi bagianbagian yang sesuai dengan kolom tabel yang ada di database. Selain itu proses parsing juga harus bisa berjalan secara otomatis agar setiap kali ada email baru yang masuk dapat langsung dilakukan proses parsing yang kemudian hasil dari parsing tersebut dieksport ke database dan ditampilkan. 


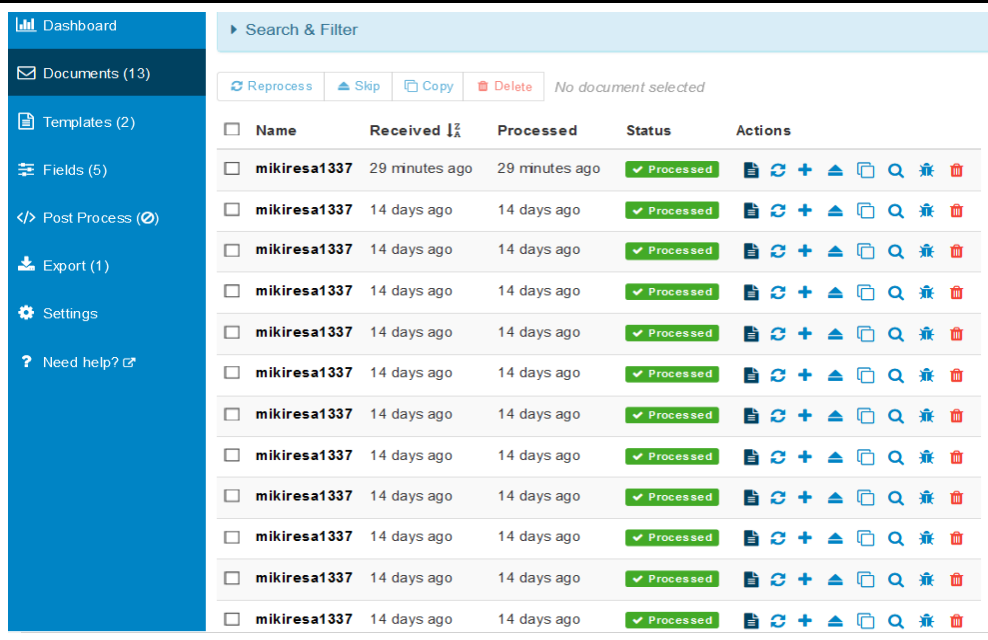

Gambar 8 Tampilan email yang berhasil diforward ke Parseur

Gambar 8 merupakan tampilan dari tool Parseur. Tool ini sudah dapat menjawab hal yang dibutuhkan penulis untuk melakukan proses parsing, Parseur dapat melakukan proses parsing secara otomatis, dapat membagi isi email menjadi beberapa bagian berdasarkan Rules yang dibuat oleh penulis. Untuk menggunakan tool ini harus melakukan konfigurasi terlebih dahulu, sepeti menambahkan email forwarding pada pengaturan Gmail yang digunakan untuk menerima log dari WebShell. Dengan menambahkan email forwarding maka email yang masuk ke Gmail tersebut akan langsung diteruskan ke email yang didafrarkan menjadi email forwarding, dalam hal ini email yang didaftarkan adalah email yang diberikan oleh Parseur sehingga email yang masuk ke Gmail akan secara otomatis juga ada di bagian Dokumen pada Parseur.

Pada bagian Dokumen pada Parseur terdepat kolom bernama Status, kolom ini berfungsi sebagai indikator yang menunjukan apakah proses parsing berhasil atau tidak nya. Apabila email yang masuk sesuai dengan Rules parsing yang telah dibuat maka email akan langsung diproses dan Status berubah menjadi Processed, apabila email tidak sesuai dengan Rules parsing maka email tidak akan diproses dan Status akan tetap menjadi Unprocessed.

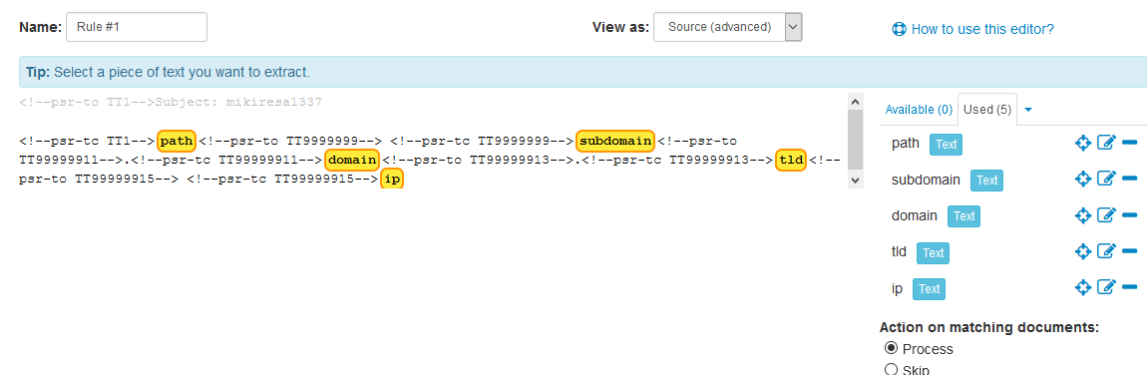

Gambar 9 Rule parsing pada Parseur

Gambar 9 merupakan pembuatan rules parsing. Agar log dapat dibagi menjadi bagian-bagian yang sesuai dengan kolom yang ada di database maka 
diperlukan rules yang sesuai agar semua kolom database dapat terisi sebagaimana mestinya dan juga untuk menghindari kegagalan pada saat proses parsing. Penulis membuat rules membagi isi email menjadi 5 bagian yaitu Path, Subdomain, Domain, Tld, IP. Pembagian ini dibuat menyesuaikan tabel yang ada di Database, selain itu penulis membuat membuat 1 rules lagi untuk melakukan parsing pada alamat yang tidak menggunakan subdomain.

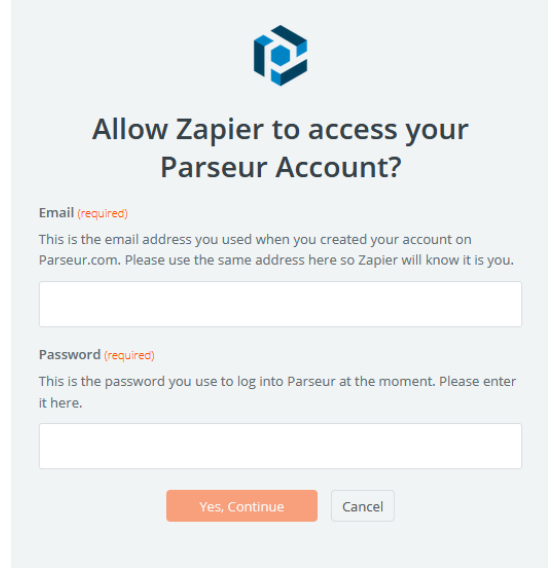

Gambar 10 tool Zapier

Gambar 10 merupakan tampilan tool Zapier. Untuk memasukan hasil parsing ke database dibutuhkan proses eksport, pada penelitian ini membutuhkan tools atau program yang dapat melakukan eksport secara otomatis dan dapat memasukan data hasil parsing sesuai dengan kolom database yang ditentukan. Untuk itu penulis memanfaatkan tool bernama Zapier, Parseur dapat diintegrasikan dengan Zapier, dengan cara melakukan pendaftaran terlebih dahulu di Zapier kemudian melakukan konfigurasi agar hasil data dari proses parsing dapat tereksport ke database sesuai dengan kolom yang telah ditentukan. Proses eksport menggunakan tool zapier berjalan secara otomatis sehingga dapat dikatakan tool ini menjadi solusi untuk kebutuhan eksport data pada penelitian ini.

Tabel 2 Tabel LogTa pada database

\begin{tabular}{ll}
\hline \multicolumn{1}{c}{ Nama } & \multicolumn{1}{c}{ Tipe } \\
\hline id & int(12) \\
subdomain & varchar(20) \\
domain & varchar(63) \\
tld & varcar(12) \\
path & varchar(200) \\
ip & varchar(15) \\
tanggal & date \\
waktu & time \\
\hline
\end{tabular}

Tabel 2 merupakan tabel yang ada di database nfrcom1_ta yang memiliki nama logta. Tabel ini digunakan untuk menampung semua data yang datang dari hasil parsing email, tabel logta memiliki 8 kolom yaitu id, subdomain, domain, tld, path, ip, tanggal, waktu. Pada kolom tanggal dan waktu diatur supaya dapat terisi 
AITI: Jurnal Teknologi Informasi

secara otomatis ketika ada data masuk ke database, oleh karena itu penulis menambahkan Trigger untuk melakukan nya. Data yang masuk pada tabel ini akan langsung ditampilkan pada website monitoring.

Tabel 3 Tabel terdaftar pada database.

\begin{tabular}{ll}
\multicolumn{1}{c}{ Nama } & \multicolumn{1}{c}{ Tipe } \\
\hline id_dom \\
dom & int(12) \\
\hline
\end{tabular}

Tabel 3 merupakan tabel yang ada di database nfrcom1_ta yang memiliki nama terdaftar. Tabel Terdaftar terdapat 2 kolom yaitu id_dom dan dom. Agar dapat memonitoring domain yang dirasa harus diprioritaskan maka dibuatlah tabel bernama terdaftar. Tabel ini digunakan untuk menampung data nama-nama domain yang akan diprioritaskan proses monitoringnya. Untuk melakukan penambahan data dapat dilakukan melalui form daftar yang ada pada website monitoring.

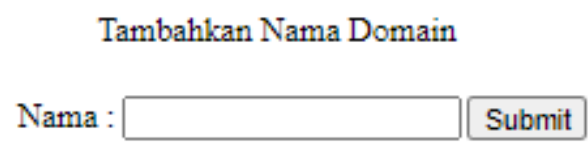

Gambar 11 Form pendaftaran domain

Gambar 11 merupakan form yang digunakan untuk mendaftarkan nama domain yang ingin diprioritaskan monitoringnya, sehingga nanti domain yang didaftarkan akan muncul pada tabel domain yang diprioritaskan.
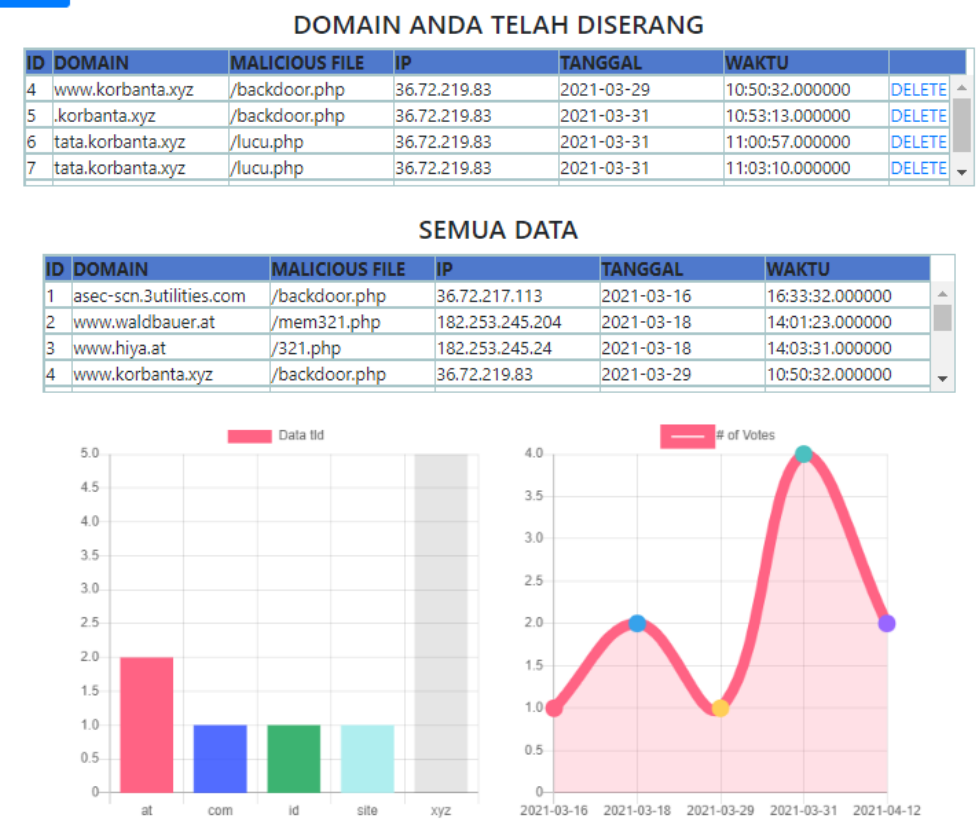

Gambar 12 Tampilan website visualisasi log. 
Gambar 12 merupakan gambar tampilan dari website visualisasi log yang penulis buat. Website ini dibuat pada domain pribadi milik penulis dengan alamat mikiresa.arisansecurity.id . website ini dibuat menggunakan bahasa pemrograman PHP dan memanfaatkan plugin Chart.JS untuk memvisualisasikan data menjadi grafik. Website ini memiliki 2 Tabel, 2 Grafik, 1 indikator serangan, dan 1 Form.

Pembuatan website ini dilakukan dengan memperhatikan data-data yang didapat dari proses parsing log, dengan tujuan agar visualisasi dari data yang didapat menjadi maksimal.

Untuk mempermudah proses monitoring maka dibuatlah indikator, grafik, dan tabel. Indikator serangan dibuat sebagai tanda apabila terdapat serangan yang datang pada domain yang telah didaftarkan, sehingga apabila terdapat domain penting yang diserang dapat diketahui dengan cepat. Tabel pertama dengan nama "Domain Anda Telah Diserang" digunakan untuk memunculkan data dari nama domain yang terdaftar atau diprioritaskan, alasan dibuatnya tabel untuk memunculkan khusus nama domain yang terdaftar adalah supaya domain-domain penting yang sudah didaftarkan dapat di monitoring dengan lebih mudah dan tidak tercampur dengan nama domain yang lain. Contoh nama domain penting yang penulis maksud disini adalah domain milik pribadi,atau jika penelitian ini diterapkan di negara atau pemerintahan berarti seluruh nama domain yang dimiliki oleh negara atau pemerintahan, atau bisa juga jika diterapkan ke perusahaan jasa web hosting yang telah menjual banyak domain, dan domain yang dirasa penting lainnya. Pada tabel domain yang terdaftar ini juga terdapat tombol berupa link bertuliskan DELETE yang dapat digunakan untuk menghapus nama website atau domain yang telah selesai diperbaiki. Sedangkan tabel yang bernama "Semua Data" digunakan untuk menampilkan semua data serangan baik untuk yang domain terdaftar maupun yang tidak terdaftar.
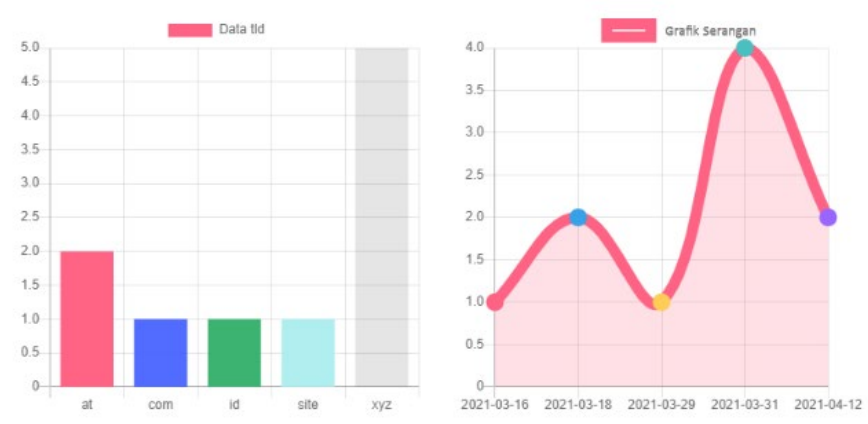

Gambar 13 grafik TLD dan Grafik Serangan Perhari

Gambar 13 merupakan gambar grafik TLD dan grafik jumlah serangan perhari. Website ini memiliki 2 grafik, grafik yang pertama digunakan untuk memunculkan informasi tentang berapa jumlah serangan pada jenis Top Level 
Domain yang sama, Grafik yang kedua digunakan untuk memunculkan informasi tentang berapa banyak aktifitas serangan disetiap harinya.

Dengan menggunakan tabel, grafik, dan indikator tersebut dirasa sudah cukup maksimal dalam memanfaatkan dan memvisualisasikan data dari log yang didapat. Selain itu tabel, grafik, dan indicator sudah dapat mempermudah pengguna untuk memonitoring dan mengetahui serangan dengan cepat.

\section{Simpulan}

Serangan pada website yang dilakukan menggunakan WebShell yang telah dimodifikasi akan mengirim email berisi informasi berupa IP Peretas, Domain, Path dimana WebShell ditanam, Tanggal, dan Waktu yang kemudian email tersebut dilakukan proses Parsing dan Eksport secara otomatis ke Database sehingga data dapat langsung ditampilkan pada Website yang digunakan untuk memonitoring serangan.

Dari hasil penelitian dan pembahasan, proses Parsing masih menggunakan tool yang berbayar sehingga memerlukan biaya untuk implementasinya, Website masih kurang menarik dan belum memiliki fitur yang lengkap sepeti Notifikasi, Map untuk memetakan lokasi serangan dengan memanfaatkan IP. Oleh karena itu saran untuk penelitian kedepan agar menciptakan tool parsing sendiri supaya tidak perlu lagi menggunakan tool berbayar, mengembangkan tampilan dan fitur website agar lebih mempermudah pengguna dalam melakukan monitoring, dan informasi yang didapatkan menjadi lebih jelas.

\section{Daftar Pustaka}

[1] D. Hariyadi, "Analisis Serangan Web Defacement pada Situs Web Pemerintah Menggunakan ELK Stack," JISKA (Jurnal Inform. Sunan Kalijaga), vol. 4, no. 1, pp. 1-8, 2019, doi: 10.14421/jiska.2019.41-01.

[2] M. Romagna and N. J. van den Hout, "Hacktivism and Website Defacement: Motivations, Capabilities and Potential Threats," 27th Virus Bull. Int. Conf., p. 10, 2017, [Online]. Available: https://www.researchgate.net/publication/320330579_Hacktivism_and_Website_ Defacement_Motivations_Capabilities_and_Potential_Threats.

[3] C. R. Sopaheluwakan and D. W. Chandra, "Anti-WebShell PHP Backdoor Scanner pada Linux Server," Ilk. J. Ilm., vol. 12, no. 2, pp. 143-153, 2020, doi: 10.33096/ilkom.v12i2.596.143-153.

[4] L. Siagian, A. Budiarto, P. Strategi, P. Udara, and U. Pertahanan, "PERAN KEAMANAN SIBER DALAM MENGATASI KONTEN NEGATIF GUNA MEWUJUDKAN KETAHANAN INFORMASI NASIONAL," J. Peperangan Asimetris, vol. 4, no. 3, pp. 1-18, 2018, [Online]. Available: http://jurnalprodi.idu.ac.id/index.php/PA/article/view/268.

[5] M. S. Umam, "Orientasi Etika dan Cyber Security Awareness (Studi Kasus pada 
UMKM di Bantul)," Akmenika J. Akunt. dan Manaj., vol. 16, no. 2, pp. 283-291, 2019, doi: 10.31316/akmenika.v16i2.394.

[6] A. R. Arianto and G. Anggraini, "Membangun Pertahanan Dan Keamanan Siber Nasional Indonesia Guna Menghadapi Ancaman Siber Global Melalui Indonesia Security Incident Response Team on Internet Infrastructure (Id-Sirtii), ' $J$. Pertahanan Bela Negara, vol. 9, no. 1, pp. 13-29, 2019, doi: 10.33172/jpbh.v9i1.497.

[7] S. Kumar and D. Agarwal, "Hacking Attacks, Methods, Techniques And Their Protection measures," Int. J. Adv. Res. Comput. Sci. Manag., vol. 4, no. 4, pp. 2252 2257, 2018, [Online]. Available: https://www.researchgate.net/publication/324860675_Hacking_Attacks_Methods_ Techniques_And_Their_Protection_Measures.

[8] G. Supriyatno, "Searching for Forensic Evidence in a Compromised Virtual Web Server against SQL Injection Attacks and PHP Web Shell," ... J. Comput. Inf. ..., vol. 12, no. 12, pp. 1057-1063, 2018, [Online]. Available: https://pdfs.semanticscholar.org/ffe6/3f26d01eacbf288d705d79f1 f78a30c886a8.p df.

[9] A. Mahmudi, "SISTEM KEAMANAN JARINGAN MENDETEKSI BACKDOOR UNTUK MENEMUKAN CELAH DAN EXPLOITS PADA WEB SERVER MENGGUNAKAN TEKNIK IDS (INTRUSION DETECTION SYSTEM)," Simki-Techsain, vol. 1, no. 4, pp. 1-7, 2017, [Online]. Available: http://simki.unpkediri.ac.id/detail/13.1.03.02.0003.

[10] I. M. Sudana, N. Qudus, and S. E. Prasetyo, "Implementation of PHPMailer with SMTP protocol in the development of web-based e-learning prototype," J. Phys. Conf. Ser., 2019, doi: 10.1088/1742-6596/1321/3/032027.

[11] L. Puad, "Pemanfaatan Phpmailer Dalam Pembuatan E-Absence Berbasis Web Mobile Sebagai Kontrol Orang Tua Terhadap Absensi Siswa," J. Akad., vol. 9, no. 1, pp. 39-44, 2016, [Online]. Available: http://ojs.unh.ac.id/index.php/akademika/article/view/207/196.

[12] I. Ramadhan, "Strategi Keamanan Cyber Security Di Kawasan Asia Tenggara: SelfHelp Atau Miltilateralism?," J. Asia Pacific Stud., vol. 3, no. 2, pp. 181-192, 2020, doi: 10.33541/japs.v3i1.1081.

[13] M. S. Hasibuan and L. M. Gultom, "Analisis Serangan Deface Menggunakan Backdoor Shell Pada Website," Techno.Com, vol. 17, no. 4, pp. 415-423, 2018, doi: 10.33633/tc.v17i4.1887.

[14] R. Andriani, E. S. Pramukantoro, and M. Data, "Pengembangan Sistem Visualisasi Access Log untuk Mengetahui Informasi Aktivitas Pengunjung pada Sebuah Website," J. Pengemb. Teknol. Inf. dan Ilmu Komput. Univ. Brawijaya, vol. 2, no. 6, pp. 2104-2112, 2018, [Online]. Available: https://j-ptiik.ub.ac.id/index.php/jptiik/article/view/1503/549.

[15] R. Faisal and S. Trhessya, "Desain dan Implementasi Deteksi WebShell Malicious Web Shell ( Backdoor Trap )," J. Sist. Inf. Bisnis, vol. 10, no. 2, pp. 188-194, 2020, doi: 10.21456/vol10iss2pp1188-194. 